Portland State University

PDXScholar

$1-2018$

\title{
Draining Us Dry: Scarcity Discourses in Contention Over Bottled Water Extraction
}

\author{
Daniel Jaffee \\ Portland State University, jaffee@pdx.edu \\ Robert A. Case \\ Renison University College
}

Follow this and additional works at: https://pdxscholar.library.pdx.edu/soc_fac

Part of the Civic and Community Engagement Commons, and the Place and Environment Commons Let us know how access to this document benefits you.

\section{Citation Details}

Published as: Jaffee, D., \& Case, R. A. (2018). Draining us dry: scarcity discourses in contention over bottled water extraction. Local Environment, 23(4), 485-501.

This Post-Print is brought to you for free and open access. It has been accepted for inclusion in Sociology Faculty Publications and Presentations by an authorized administrator of PDXScholar. Please contact us if we can make this document more accessible: pdxscholar@pdx.edu. 


\title{
Draining Us Dry: Scarcity Discourses in Contention Over Bottled Water Extraction
}

\section{Daniel Jaffee ${ }^{1}$ and Robert A. Case ${ }^{2}$}

This is an Accepted Manuscript of an article published by Taylor \& Francis Group in Local Environment on 17 January 2018, available online: http://www.tandfonline.com/10.1080/13549839.2018.1431616

Citation: Daniel Jaffee and Robert A. Case. 2018. "Draining Us Dry: Scarcity Discourses in Contention over Bottled Water Extraction.” Local Environment 23(4): 485-501. Doi: 10.1080/13549839.2018.1431616

\begin{abstract}
Water scarcity is a highly contested concept. The dominant narratives of water scarcity in policy debates have been criticized for prioritizing purely quantitative metrics and eliding questions of inequality and power. While much scholarship on water scarcity examines contexts in the global South where potable water infrastructures do not reach most residents, this article examines conflict over commercial water extraction in a Northern setting where access to potable tap water is nearly universal, yet local water supplies are increasingly constrained. It addresses three main questions: 1) How are narratives or discourses of water scarcity mobilized by a range of actors in local conflicts over groundwater extraction for water bottling?; 2) To what extent do such discourses invoke biophysical versus socially-produced scarcity, current versus future scarcity, and local versus regional or global scales of scarcity?; 3) What are the implications of the findings for efforts by environmental advocates and communities to protect local water supplies? We explore these questions by analyzing a local case study of conflict over groundwater extraction by the leading bottled water firm, Nestlé Waters, in southwestern Ontario, Canada. We find that the scarcity narratives deployed by local residents, activists, public officials, and bottling industry representatives illustrates the use of several forms of figurative conflation involving geographic and temporal scales of water scarcity, and economic and volumetric forms of scarcity. We argue that this conflation illuminates deeper issues of economic and social justice at the heart of the conflict, which transcend reductionist hydrological assessments of scarcity or abundance.
\end{abstract}

\footnotetext{
${ }^{1}$ Department of Sociology, Portland State University, Portland, OR, USA. Email: jaffee@pdx.edu

${ }^{2}$ Social Development Studies, Renison University College, Waterloo, Canada.
} 


\section{Discourses of Scarcity in Contention over Bottled Water Extraction in Ontario, Canada Daniel Jaffee and Robert A. Case}

Since 2015, the commodity of bottled water and its social and environmental impacts have filled news headlines as never before. After the environmental justice crisis of lead contamination in Flint, Michigan was revealed, city residents were obligated to replace their toxic tap water with bottled water for drinking for over a year (Wagner 2016). In 2016, bottled water surpassed soft drinks as the most consumed beverage in the United States (Beverage Marketing Corporation 2017). The waste generated by the soaring global consumption of plastic water bottles, now nearly 500 billion per year, has been characterized as an ecological threat "as dangerous as climate change" (Laville and Taylor 2017). And despite news that Nestlé and other major bottlers were continuing to extract groundwater on long-expired permits amid California's historic drought in 2015, the CEO of Nestlé Waters defiantly told an interviewer that "If I could increase [water bottling in the state], I would" (Neate 2015).

This relatively new commodity intersects with a range of major social and political trends, among these the market's persistent incursion into the commons and the public sphere, the individualization of protection from environmental risk, the deterioration of public infrastructure under neoliberal austerity, and declining trust in public tap water. A far less well explored issue, however, is the relationship between the growth of the bottling industry and water scarcity, at scales ranging from the very local to the global.

Water scarcity is a highly contested concept. The dominant narratives and frames of water scarcity in policy debates have been criticized by many scholars for prioritizing purely quantitative metrics and eliding questions of poverty, unequal water access and distribution, and the appropriation of water by powerful interests and the wealthy (e.g., Swyngedouw 2009, 
Jairath 2010, Ioris 2013). The bulk of this literature examines contexts in the global South in which piped potable water infrastructures do not reach most residents. This paper, in contrast, examines conflict over commercial water extraction in a setting in the North where state provision of potable tap water is nearly universal, yet local water supplies are becoming increasingly constrained. While the dimensions of "scarcity" in such economically privileged settings are far removed from the life-and-death implications for residents in peripheral contexts in the South and parts of the North who lack access to basic drinking water services, they nonetheless offer a useful lens for comparing contestation over industrial water extraction across these multiple loci.

In this article, we address three principal research questions: 1) How are narratives or discourses of water scarcity mobilized by a range of actors in local conflicts over groundwater extraction for water bottling?; 2) To what extent do such discourses invoke biophysical versus socially-produced scarcity, current versus future scarcity, and local versus regional or global scales of scarcity?; 3) What are the implications of the findings for efforts by environmental advocates and communities to protect local water supplies? We explore these questions by analyzing a local case study of social conflict over groundwater extraction by the leading bottled water firm, Nestlé Waters, in southwestern Ontario, Canada.

In the following section, we review the contested definitions and framings of natural resource scarcity generally and water scarcity in particular, trace debates over the political economy of water scarcity, and discuss how scale is deployed discursively in struggles over water use. We then review the dramatic global growth of bottled water, and the substantial contestation that has accompanied it. The subsequent section describes the conflict over Nestlé's groundwater extraction activities in southwestern Ontario, Canada, and the company's proposals to expand 
those water takings. We then present the findings from our ethnographic research with a range of participants in this controversy, followed by a discussion of the findings relative to our research questions, in which we offer a typology of scarcity discourses used by the various actors in the conflict. The water scarcity narratives deployed by local residents, activists, public officials, and bottling industry representatives, we find, illustrate the use of several forms of figurative conflation involving geographic and temporal scales of water scarcity, and economic and volumetric forms of scarcity. We argue that this conflation illuminates deeper issues of economic and social justice at the heart of the conflict, which transcend reductionist hydrological assessments of scarcity or abundance. The paper concludes by reflecting on the implications of this analysis for efforts by environmental advocates and communities to protect local water supplies.

\section{Constructing and contesting water scarcity}

Resource scarcity, observes Harvey (1974), "is in fact necessary to the survival of the capitalist mode of production, and it has to be carefully managed, otherwise the self-regulating aspect to the price mechanism will break down." A century earlier, Marx (1867) had identified the roots of scarcity in the structure of market institutions and the private appropriation (and degradation) of nature by capital (Ioris 2012). While central to the discipline of economics, scarcity is a contested concept that reflects fundamental tensions among divergent currents of scholarship.

Despite its widespread use in the water management literature, there is no commonly accepted definition of "water scarcity" (Rijsberman 2006). Rather, the term is used by various authors to describe both "permanent and temporary, natural and human induced phenomena of low water availability" (Spiliotis and Garrote 2015, p. 522). Jaeger et al. (2013) write that while 
aggregate indices of volumetric water scarcity are widely used and fairly straightforward, they do not adequately reflect spatial and temporal inequities (p. 4506). Nor do they address economic inequality.

More critical social science perspectives emphasize water scarcity as socially constructed. Implicit in the question "is there enough water?" are the accompanying questions "enough for what and whom?" and "who is able to access the water?" One of the central concerns of scholarship on the political ecology of water is to illustrate "the fundamentally socially produced character of ... inequitable hydro-social configurations" (Swyngedouw 2009, p. 57). Loftus argues that political ecology "seeks to politicize understandings of the distribution of water," based on an understanding that "water and social power are...mutually constitutive" (2009, pp. 953, 959). An important current in this literature examines contested framings of water scarcity, drawing primarily on case studies in the global South. In their examination of the politics of water reallocation in India, for example, Joy et al. (2014) argue that although water scarcity "is often presented as a natural problem rather than one of distribution or social relations of power," it is "always also deeply mediated by humans and codetermined by power relationships that construct scarcity far beyond just the wickedness of nature" (p. 960). Mehta's work on water scarcity in the arid Indian state of Kutch (2007) examines how state officials promoted scarcity narratives that framed the solution to periodic droughts and groundwater depletion as augmenting the supply of water to the region. The state and elites ignored effective small-scale solutions for water conservation and storage, focusing solely on completing a mega-canal to carry water from the distant Narmada Valley dams, despite the fact that this water was appropriated by powerful agricultural and industrial users and never reached the poor rural dwellers who were the purported beneficiaries. Investigating peri-urban water problems in Lima, 
Peru, Ioris (2012) similarly locates the roots of inadequate residential supply in "the intersection of poverty and inequality," and calls for a "non-essentialist" interpretation of the contested concept of water scarcity (p. 613).

The large majority of this literature draws on cases from the global South. While some scholars have examined the dynamics of contention over water scarcity in the North (e.g., Bakker 2000, Otero et al. 2011, Kaika 2003, Diekmann, Gray, and Baker 2017), this work focuses primarily on struggles over provision of and access to municipal water. Few studies have explored contexts involving groundwater extraction by transnational corporate actors such as water bottling firms, and even fewer focus explicitly on discourses of scarcity in those settings, gaps this paper contributes to addressing.

Just as water scarcity is socially and politically constituted, so is the use of scale in characterizing and contesting that scarcity. Zwarteveen and Boelens observe that " $[\mathrm{t}] \mathrm{emporal}$ and geographical scales are always socially constructed, and hence contingent and dynamic, with the choice and definition of scales and scalar configurations sometimes themselves being contested in struggles over what is fair or equitable. Indeed, 'jumping' scales can be an effective strategy to make injustices disappear" (2014, p. 151). This approach informs the notion of figurative conflation that we develop in our analysis below. Our aim in identifying this conflation is not to assert that the respondents are literally confusing scales or forms of scarcity, but rather to analyze how such scalar ambiguity—for example, the multiple, nested levels of watersheds - can be strategically or tactically deployed by a range of actors in a local conflict over water extraction. 


\section{Bottled water, extraction, and contestation}

The growth of bottled water has been meteoric. Since 1980, consumption of this commodity has risen in all but two years, both globally and in North America. Bottled water consumption in the U.S. grew from 29 gallons per capita in 2011 to over 39 gallons in 2016 (Rodwan 2017) placing it fourth behind Mexico, Thailand, and Italy, but well ahead of Canada, at 18 gallons (Euromonitor International 2017). China's total bottled water use has nearly doubled since 2011 to over 22 billion gallons, accounting for almost one-fourth of global consumption (Rodwan 2017). The worldwide bottled water market - estimated at $\$ 158$ billion in 2014 and projected to

nearly double by 2020 - is dominated by four global food and beverage corporations: Coca-Cola, Pepsico, Danone Group, and Nestlé, the leading firm (Transparency Market Research 2015).

Central to bottled water's growth is the commodification of a substance that has long been treated as a public good and a "material emblem of citizenship" (Bakker 2010). Numerous scholars have employed Harvey's influential framework of accumulation by dispossession to analyze water grabs and municipal water privatization (Ahlers 2010, Roberts 2008, Spronk and Webber 2007, Perreault 2013, Torres 2012), but only a few studies have applied this analytic to the equally transformative dynamics of enclosure at work with bottled water (Jaffee and Newman 2013a, Sitisarn 2012).

The factors behind bottled water's dramatic rise vary by geography, shedding light on the political economy of this commodity. In many parts of the global South, due to rapid urbanization, colonial legacies, the constraints of debt and structural adjustment, and other factors, states have been unable or unwilling to extend piped tap water networks to the majority of urban and peri-urban residents. In this context, bottled water has increasingly been embraced by consumers, states, and corporations as the solution to perceived or actual scarcity of clean 
drinking water (Hawkins, Potter, and Race 2015). These dynamics highlight both the socially produced nature of that scarcity and the troubling implications for realizing the human right to water. The cost of this commodified water is prohibitive for many poorer residents, who may be forced to choose between food and clean water (Greene 2014).

In nations where potable tap water is nearly universally available, the reasons for bottled water's ubiquity are somewhat different. A recent study found that among U.S. adults, bottled water accounted for 44 percent of total drinking water consumption (Drewnowski, Rehm, and Constant 2013), even though it costs up to 10,000 times more per unit volume than tap water (NRDC 1999). The bottled water industry promotes its product with marketing focused primarily on health, active lifestyles, convenience, and taste, but bottled water's growth has also been driven by the industry's disparagement of tap water, both explicit and subtle (Gleick 2010). News coverage of instances of unsafe tap water — whether brief or long-term — further increase demand for bottled water, despite the fact that in both the U.S. and Canada bottled water is less regulated than tap water, and at least as likely to contain contaminants (Gleick 2010).

Holt (2012) argues that, regardless of the reality, perceptions of poor tap water quality have become established in the public consciousness in North America, leading to an "ideological lock-in" that necessitates challenging bottled water on the terrain of culture, not merely politics. Szasz (2007) cites bottled water as a prime example of what he terms "inverted quarantine": the individualization of responsibility for protection against environmental hazards, which reduces demands on government for regulation and oversight. Neoliberal austerity has led to substantial disinvestment from maintenance of public water infrastructure, leaving local governments with a maintenance backlog estimated at over $\$ 1$ trillion in the U.S. alone (American Water Works Association 2012). 
Both in North America and globally, bottled water has generated a range of vocal countermovements, which fall into two broad categories: those challenging bottled water consumption, and those opposing water extraction by the industry. On the consumption end, "take back the tap" movements have succeeded in pushing city governments (including San Francisco and Toronto) and other public institutions to ban public purchasing and/or sales of bottled water, repair and reinvest in public water infrastructure, and promote tap water quality and access (Lagos 2014, Gentile 2008). One major impetus for these campaigns is the substantial negative environmental externalities of bottled water, including dramatically higher carbon footprints (Gleick and Cooley 2009), water waste in manufacturing, and the voluminous plastic waste generated worldwide by its disposal (Laville and Taylor 2017).

Grassroots movements have also contested groundwater extraction by the bottling industry in both South and North. Although the volumes extracted for bottling are often minuscule relative to total water usage, this water mining can have significant and potentially irreversible hydrological and ecological effects in particular localities, including aquifer depletion, loss of irrigation and well water, and drinking water contamination (Gleick 2010, Barlow 2014). The case of Plachimada, India, is one well-documented example, involving an ongoing struggle by local residents and farmers against pumping by Coca-Cola that depleted and contaminated local groundwater reserves upon which they depend for survival (Raman 2010, Sitisarn 2012, Aiyer 2007).

In North America, much of this facet of contention has focused on Nestlé, the largest bottler of spring water, which now owns 15 brands and has 29 bottling facilities in the U.S. and Canada (Nestle Waters North America 2013). Proposals by Nestlé to site or expand pumping and bottling facilities in rural communities across North America have drawn vocal grassroots 
opposition, with residents raising concerns including water table depletion, the impact of truck traffic, and the minimal water rates paid by bottlers (Jaffee and Newman 2013a, Fumano 2013, Snitow, Kaufman, and Fox 2007).

Some authors have studied sites of contention over water extraction by the bottled water/beverage industry in the global South, notably in India and Pakistan (Drew 2008, Sitisarn 2012, Rosemann 2005). Other work focuses on the discursive factors contributing to the growth of bottled water consumption, particularly marketing and branding (Wilk 2006, Brei and Tadajewski 2015, Hawkins and Emel 2014). However, little scholarship examines the discursive elements of local contestation over water extraction by bottling firms in the global North (exceptions include Case 2016a, 2016b, Hawkins, Potter, and Race 2015, Jaffee and Newman 2013a).

This article contributes to addressing these lacunae. Mehta argues that scholars need to focus simultaneously on two levels of contestation over water scarcity: both at "the discursive level where scarcity is 'constructed' and... at the material level as a biophysical problem where it is lived and experienced" (2007, p. 661). The following sections embrace this invitation in applying such a dual lens to the analysis of a local and regional conflict over groundwater extraction for water bottling.

\section{Case study context}

Wellington County is a predominantly rural region of southwestern, Ontario, Canada, close to the major urban center of Toronto to the east, with a population of 222,726 in 2016 . The university city of Guelph, located in the center of the county, contains about half of these 
residents (Statistics Canada 2016b). ${ }^{3}$ Wellington County's population is projected to grow by over 100,000 by 2041 (Province of Ontario 2017).

The county is entirely dependent on groundwater for all domestic, agricultural and industrial uses (GRCA 2016). Since at least 2006, the office of Ontario's Environment Commissioner has raised concerns about the ability of the county's municipalities to meet source water and wastewater demands associated with the projected growth (Miller 2007, p. 28). Drought conditions, declared and ranked for severity by the Grand River Conservation Authority, have been a regular feature of the summer months for nearly two decades. These declarations trigger mandatory restrictions on outdoor residential water use in most municipalities, accompanied by fines, public education, and other conservation measures, but do they not impose mandatory limits on industrial or agricultural use. As a result of these and other factors, there is a high degree of public awareness of water issues in Guelph and Wellington County.

In 2000, Nestlé Waters Canada purchased the Aberfoyle Springs bottled water brand and its facilities in Aberfoyle, in the southern end of the county, establishing its national headquarters there, along with Canada's largest water bottling plant. Since 2005, Nestlé has received provincial permission to extract up to 3.6 million liters per day from its Aberfoyle well. The purchase also included a second well located in Hillsburgh, in the eastern part of the county, from which Nestlé extracts up to 1.1 million liters per day, transporting it 30 miles in tanker trucks to Aberfoyle for bottling. (Figure 1 shows the locations of Nestlé's well sites and bottling facility.)

It was not until 2007, however, that opposition to bottling began to emerge in the community. When Nestlé filed an application with the provincial government for a 10-year renewal of its

\footnotetext{
${ }^{3}$ Guelph is politically independent of the County, but integrated with it economically and in terms of networks of water contestation, so we include it as part of Wellington County for the purposes of this article.
} 
Figure 1. Wellington County, Ontario, with Nestlé Wells and Bottling Plant

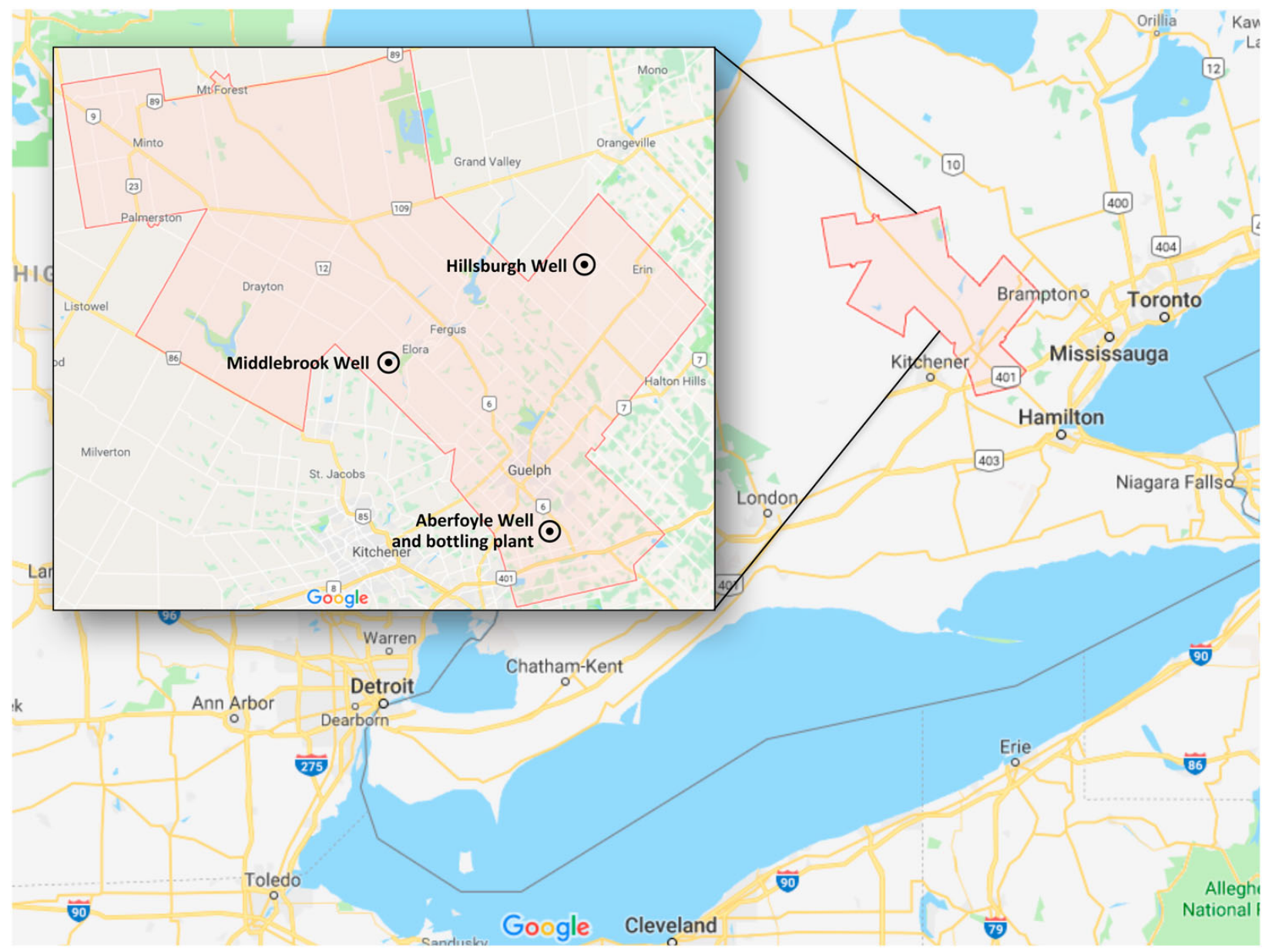

water-taking permit at Aberfoyle, a group of local residents formed the Wellington Water Watchers (WWW), a nonprofit organization dedicated to "the protection of local water and to educating the public about threats to the watershed" (Wellington Water Watchers n.d.). In May 2007, WWW mobilized over 7,000 local residents to send letters to the Ontario Ministry of the Environment (MOE) challenging Nestlé's permit renewal. Overwhelmed by the unprecedented public response, the MOE delayed its decision by a year, but finally approved the permit. Although water activists were disappointed by the decision, the public involvement did alter the application review process and caused some small but significant conditions to be placed on 
Nestlé's permit. The campaign also helped to establish WWW as one of the more effective and influential Canadian water advocacy organizations.

Since 2007, WWW and allied groups have contested every permit application for water bottling in the county, with varying degrees of success. In late 2012 concerned residents in Erin Township, organized by WWW along with the local group Friends of Hillsburgh Water, publicly demonstrated in opposition to Nestlé's renewal application for groundwater pumping at the Hillsburgh well. Although its application was granted, Nestlé reignited public anger by appealing its new permit, arguing that it unfairly included mandatory restrictions on water taking during drought conditions, which the firm argued should be voluntary. Faced with renewed opposition and generally hostile national media coverage (e.g., Paris 2013), Nestlé eventually backed down and withdrew its appeal.

In 2015, Nestlé moved to expand its groundwater takings to a third location, near the historic town of Elora in Centre Wellington township. The company secured an option to purchase the Middlebrook Well from a small, defunct bottler in order to supply its Aberfoyle plant. If it is approved, Nestlé would extract up to 1.6 million liters per day from the Middlebrook site, bringing its total daily water takings in the county to 6.3 million liters. When news broke that Nestlé had moved to buy the well, local residents quickly organized into the grassroots group Save Our Water, to build opposition to Nestlé's plans (Save Our Water n.d.). By late 2015, their efforts had begun to draw national media attention (e.g., CBC News 2015). Save Our Water and WWW jointly launched a campaign to pressure government officials to reject Nestle's applications for test pumping at the Middlebrook site and permit renewals for the other wells. As drought conditions returned in summer 2016 and the controversy surrounding Nestlé's watertaking operations in the county grew, Nestlé waived all conditions and purchased the 
Middlebrook well outright, in order to stop a second bidder. That bidder turned out to be the Township of Centre Wellington, which had determined the well to be vital for future public water supply in the context of a growing population (Kassam 2016).

By late summer 2016, opposition to groundwater taking for bottling in the county had become organized and vocal enough to capture the attention of the highest provincial officials. In August, Ontario Premier Kathleen Wynne declared — as local activists had insisted — that the province's permit-to-take-water system, particularly for water bottling, was out of date and needed to be changed. In December 2016, the provincial government imposed a two-year moratorium on new or expanded permits to take water for bottling in Ontario, in order to conduct a full review of the province's groundwater resources and the regulatory process for water takings (Leslie 2016).

This moratorium - a virtually unprecedented move, and a significant victory for local water activists - means that Nestlé cannot proceed with plans to pump water from the Middlebrook well until at least January 2019. To the disappointment of WWW and other groups, however, applications to extend the existing bottling permits will proceed. The Premier also announced a major increase in extraction fees for water bottling, from $\$ 3.71$ per million liters to $\$ 503.71$, effective August 2017 (Benzie 2017). With additional regulatory changes in progress as of this writing, and provincial elections scheduled for mid-2018, the conflict over bottled water in Wellington County promises to influence environmental politics at the provincial level for the foreseeable future.

\section{Data and research methods}

The data analyzed below are drawn from field research carried out between April 2015 and August 2016. During this period we conducted semi-structured interviews with 22 respondents, 
including staff, volunteers, and board members of the primary water advocacy organization, leaders of other regional and local environmental organizations, community residents, a municipal environmental services employee, and local elected officials. The interview data were supplemented with media coverage, press releases, campaign materials, and public communications by various stakeholders collected between April 2015 and July 2017.

We initially identified key informants active with the key water advocacy NGO in this controversy (Wellington Water Watchers), and proceeded to identify additional respondents via snowball sampling. We selected respondents from this pool to interview with the aim of achieving a sample broadly representative of the major categories of participants within the region around this issue. Table 1 provides a breakdown of the respondents by affiliation. We conducted a total of 23 semi-structured interviews, three of which were group interviews. Five respondents were interviewed on multiple occasions. The interviews lasted between 45 minutes and two hours. All interviews were conducted in person by one of the researchers, and were audio recorded and transcribed.

Table 1. Number of respondents and interviews by affiliation

\begin{tabular}{lcc}
\hline Respondent affiliation & Number of respondents & Number of interviews \\
\hline Water advocacy organisation staff/board/volunteers & $3^{\mathrm{a}}$ & $7^{\mathrm{a}}$ \\
Community residents & $9^{\mathrm{a}}$ & $6^{\mathrm{a}}$ \\
Other local environmental organisation/network & 6 & 6 \\
Local government staff & 1 & 1 \\
Public elected officials & 3 & 3 \\
Total & $22^{\mathrm{a}}$ & $23^{\mathrm{a}}$ \\
\hline
\end{tabular}

Indicates multiple interviews of same respondents.

Data analysis was conducted jointly by both researchers. We took an inductive approach to analysis, first open-coding the transcripts and then identifying emergent themes (Emerson, Fretz, and Shaw 2011). While we quote only from a subset of the interviews in this article due to 
length considerations, the totality of the interview data informs the broader analysis.

Additionally, the news media coverage and organizational communications by water advocacy organizations (websites, blogs, campaign materials, etc.) were reviewed for corresponding themes and used to contextualize the themes identified through analysis of the interview data. In the following section, we summarize the results of this analysis.

\section{Findings: scarcity discourses}

A number of key threads emerged from our analysis of the interview data that illuminate the broader questions regarding scarcity introduced earlier. The first is the central role of drought in framing and catalyzing opposition to commercial water bottling, including varying temporal and scalar understandings of the connection between drought and scarcity. A second is the relationship between water removal from local aquifers and scarcity, as well as conflicts between present extraction and projected future demand. A final theme involves the perceived risks and costs of increased water extraction for local communities, and conflicts between water commodification and public needs. This section explores these themes, with particular attention to the discursive elements of contestation over continued and expanded groundwater extraction.

\section{Drought, scarcity, and equity}

One of the most frequent themes voiced by respondents involves the recurring summer droughts in the region and their relationship to water scarcity. Many people juxtaposed Nestlé's ongoing water extraction against the restrictions on residential water use imposed in the region each summer, which some see as indicating not merely seasonal but long-term volumetric scarcity. One member of a local water advocacy organization described the situation during the most severe drought in recent years, emphasizing the inequity between these implicitly competing uses: 
Well, the one that got the biggest attention, again, was the drought issue that we brought forward when Nestlé was still pumping at full rates when everybody else had to cut back. In 2012 , basically it was water lock-down. There was no water. It was drought everywhere, there wasn't a drop. The rivers were dry, people's wells were going dry... There seems to be two levels of priority here - corporate gets full amount and citizens get a rationed amount.

A founding member of WWW, describing the same drought of 2012, discussed how this contrast informed the organization's campaign opposing Nestlé's water extraction:

$[\mathrm{S}] \mathrm{o}$, we were experiencing these drought conditions and having to comply with these regulations enforced by the City. But Nestlé was merely pumping as much water as they wanted to, and we thought, "No, that's not right! There should be restrictions on watertaking for commercial bottling as well as residential use." It's only fair.

The group used this perceived contradiction in a public campaign and legal battle over the conditions placed on Nestlé's renewed provincial permit for its Hillsburgh well in 2013, which resulted in a partial victory for WWW when Nestlé abandoned its challenge to mandatory drought restrictions.

This tactic and the quotes above illustrate how, even though the spatial scales of the drought (regional), the water use restrictions (watershed and municipal) and the groundwater pumping (aquifer-specific) are not commensurate, water activists viewed the inequity in the way residential and industrial water users were regulated during drought periods as a potent issue for mobilizing public opposition.

However, not all respondents accept the premise that recurring droughts or water use limitations signify longer-term volumetric shortage or scarcity. "Those [residential use] restrictions ... [are] minimal, not huge," said a local elected official:

There's never an issue of, we can't drink the water, or you can't have showers, or you can't run your taps. It's never come to that, and there's no expectation that it would. But the Nestlés thing brought that whole sort of concept to the fore, and then the advocate people picked that up and ran with it. 
Nestlé goes to great lengths to emphasize that its water extraction in the region is insignificant in volumetric terms. According to a document on the company's website, "The bottled water industry in Canada uses just $0.6 \%$ of the PTTWs [Permits to Take Water] in the Grand River watershed and just $0.2 \%$ of permitted water in Canada" (Nestle Waters Canada 2016). Nonetheless, as we discuss below, the removal of this groundwater from local and regional watersheds has provided another effective frame for Nestlé's opponents.

While respondents most often referred to drought affecting the local area, some discussed how even geographically distant drought can catalyze concerns about the local impacts of water bottling. According to a WWW board member, bottled water consumption "is not growing in Canada...but the awareness is also growing at a tremendous rate. And a lot of that has come from California drought and B.C. drought information, not because of local information. The images from California have hit strong here. Very strong."

Although this linkage has not been a central element of the organization's messaging, WWW has mobilized such images of distant drought to dramatize the finiteness of local (ground)water in Ontario, an example of what we term spatial conflation - a blurring of scales that in this case is strategic. The other respondents above, while opposing Nestlé's unrestricted pumping during the drought on equity grounds, engage in spatial conflation as well—though perhaps unintentionally — by linking the groundwater extraction from particular (geologically- and geographically-bounded) local aquifers with the regional scale of recent episodic droughts. They also engage to varying degrees in temporal conflation, linking seasonal droughts to longer-term depletion and scarcity. 


\section{Water "export," growth, and future scarcity}

A second set of themes revolves around the removal of water from the local area via bottling, the potential conflicts this poses with future public water needs, and anticipated future scarcity linked to climate change.

Many respondents vocalized a conviction that local (ground)water supplies are finite, and that by removing water from local aquifers or watersheds, extraction for bottling contributes to long-term depletion and diminishing water availability. "The main issue that we're concerned about is the long-term issue of will we have enough water in our reservoir," said one local grassroots activist. “[W]e are concerned long-term because Nestlé is just a company-they'll just move when the water is done. They'll just pick up and move and go somewhere else, and for us as a city, we're not moving the city, right?" A local municipal councilor addressed the concern about water removal in blunter terms: “[T]he Nestlé thing, they say...that the water stays in the watershed. Well, that is such garbage. That is such bullshit." The two principal water advocacy groups, WWW and Save Our Water, have explicitly framed groundwater extraction for bottling as "water export," leveraging widespread concern among Canadians about loss of control over the nation's freshwater supplies. Save Our Water, for example, has disseminated an infographic that depicts water being pumped out of an aquifer and into a long line of tanker trucks, with the caption, "1.6 million liters per day; Trucked away forever."

In contrast, Nestlé works to counter the notion that it contributes to long-term groundwater depletion. Nestlé Waters Canada spokesperson Andreanne Simard argued that "[w]e have 15 years' worth of data...that shows that the long-term sustainability of the aquifer is not impacted by our operation" (CTV News 2016). Water advocacy groups respond by pointing to 
hydrological studies that they claim show Nestlé's pumping at its large Aberfoyle well is depleting the local aquifer.

Several respondents identified a conflict between groundwater pumping for bottling and the future water needs of a growing local population. Given the context of regional land-use policy, concerns about population growth in the county are not hypothetical. "[B]asically there's not enough water to give the water to Nestlé and still have growth here in the township," argued one Elora resident:

We have a fairly fragile and vulnerable water system in our township. And we're also due to double in size in the next 20 years, with something called Places to Grow legislation. So if we double in size and we already have a fragile vulnerable system, we have some troubles, we have some problems. So we need to address that as well as the water taking permit.

A member of WWW linked this issue to the drought and to increasing public perceptions of water shortage:

The combination of the severe drought this year and the fact that there's been so much media on what's happening, has made people realize that the water's scarce. Now, there's a double edge to the sword. Many know that it's required for growth, but a lot of people don't want the growth... But unless the legislation changes, Elora is going to be forced to accept growth at a certain level over the next 20-30 years. But the new evidence unequivocally points to the fact that this water shouldn't be leaving - it's going to be needed for the citizens.

The expectation that increased demand from population growth will overtax local groundwater is not shared by all. A town councilor in Centre Wellington argued that water supplies are sufficient, with some caveats:

[A]s far as anybody knows, there's plenty of water for anybody who's here now and any reasonable projected use ... droughts come and go, people get all excited about it, then it rains for a year, and people forget about it. But it's more just people looking long-range, knowing you've got this tidal wave of big growth coming, even though models and science says you have enough to deal with it... But if there was a problem - and growth-you could see a potential where it could become a constraint.

Other respondents mentioned climate change as an additional stress on local groundwater. "A water bottling plant here...just doesn't make sense," opined another local elected official: 
I don't know if I'd call myself an environmentalist, but I think it's the wrong thing to be doing with climate change, and not knowing where we're going, what's going to happen. We already had the knowledge from our previous water studies that said that this was an area where water could become a problem in the future. So I knew that already. So, having 1.6 million liters per day leave the aquifer makes no sense to me.

Worth underlining in this quote is the premise that the extracted water will leave the aquifer permanently, putting present water bottling and future residential use into direct conflict. A local resident also invoked climate change, linking water scarcity on local and international scales, and underlining how WWW's messaging has strategically employed this spatial conflation:

[I]f you're talking about climate [change], you're talking a lot about water and access to water. And look what's happening even in California right now. So there's such a close connection. It was through Wellington Water Watchers that I really understood how little freshwater there is in the entire scheme of things.

Intriguingly, these frames have also percolated into governmental discourse on the bottled water industry, as we discuss in the conclusion.

\section{Commodification, harms versus benefits, and economic scarcity}

A final set of themes revolves around the tension between the risks and benefits of increased extraction of local water for bottling, and between market control over water and present or future public needs. Several respondents discussed the risks or costs to local communities of commercial water bottling, relative to the meager or nonexistent benefits. A town councilor addressed this calculus, highlighting how local water advocacy groups had effectively deployed concerns about the harms of water bottling in their anti-Nestlé campaigns:

[T]hey started raising those things as issues - not "Nestlé's a horrible corporation that exploits their workers in the Third World." [But] it's, "what is Centre Wellington gonna do about the impacts on infrastructure, the growth impact? And the logical question from that is, "Ok, where's any benefit to us from that?" They're not gonna run a big plant there, they're not gonna employ a lot of people, they're not gonna pay a lot of taxes. They're just gonna suck the water out, truck it away, and we'll never see it again. So that made sense to all kinds of people. 
Other interviewees more directly challenged the acceptability of commodifying local groundwater through commercial bottling, some of them directly invoking claims of scarcity. "[Y]ou can have all the technical arguments you want," said a WWW member, and I think it's always going to show in favor that this water is scarce. But a fundamental decision as a society: is this how we want to treat our water, is this how it should be permitted and sold or given away? And it comes down to that, and a lot of people have basically said no - this is not an acceptable use or permit for the water.

Even some respondents who rejected the idea that Nestlé's water extraction contributes to scarcity nonetheless viewed the benefits as insufficient to justify the costs. "[B]ottled water does tend to really rally people," said an elected municipal councilor, "even though I'd have to say the amount of water taken by bottling companies is minuscule compared to a lot of the other usage. It is just that it is such a ridiculous use of our ground water so it can grab people."

A related concern is that the private control entailed in water bottling will ultimately lead to economic scarcity, making water unaffordable or unavailable for future public needs. According to a Centre Wellington town councilor,

The one risk you can't address is: there's a potential source of potable water for the future of this township that is now in private hands, that wasn't before. So therefore either it's not accessible, or only if you pay them a gazillion dollars to expropriate it.

In this final set of quotes, water commodification in the present is viewed as ultimately transgressive or unacceptable, in part because it forecloses access to finite groundwater supplies for future use by local residents and other worthy uses. In other words, these respondents frame market control over local water as creating or exacerbating scarcity-either in the present or the future - and they imply that some test of social or public good is needed to justify groundwater extraction. Interestingly, this approach illustrates an attributional conflation that fuses economic and volumetric formulations of scarcity, echoing the political ecology scholarship that criticizes 
purely quantitative scarcity metrics for obscuring enclosures of the water commons by powerful actors.

\section{Discussion}

In this section we analyze how the interview data illuminate both our original research questions and broader themes in the literature on water scarcity. With regard to the first research question, regarding how narratives or discourses of water scarcity are mobilized by a range of actors in this conflict over water extraction, three major sets of themes emerged in our analysis of the data. The first is the key role played by drought, and the inequity between groups of water users that is accentuated by drought, in shaping the terms of contention over water extraction. The recurring droughts greatly aided the efforts of local water activists to educate the public about unsustainable (ground)water use, particularly when combined with dramatic news coverage of droughts occurring elsewhere in North America. This enabled advocates and local residents to engage in both spatial (or scalar) conflation and temporal conflation, linking scarcity in the present and future and at different geographic scales - for example, by connecting droughts in California and Ontario. Moreover, the droughts highlighted water injustice, as drought-induced water use restrictions threw into sharp relief inequalities in the ways different groups of users were treated. By seizing on the stark inequity between how residential and industrial water users were regulated, activists were able to tap a rich vein of local resentment, allowing them to highlight the socially-produced nature of "scarcity" in this context.

The second key theme is the removal of "local" water by commercial bottling for consumption in distant watersheds, along with the issue of population growth and anticipated conflicts between future water demand and industrial extraction. Water removal has proven to be especially fertile discursive terrain for water activists in this region. The choice by WWW 
and Save Our Water to frame packaging and removing local groundwater as water "export" has been a provocative and effective rhetorical move. While of course there are nested scales of watersheds, and a portion of the Nestlé water bottles shipped from southwestern Ontario will remain within the huge Great Lakes watershed, much of it will leave even that basin.

Moreover, the export framing makes a conceptual leap to encompass true international exportation. It takes advantage of longstanding concerns among Canadians about plans for bulk freshwater exports to the U.S. and other nations. Despite the ban on large-scale water diversions in the Great Lakes Compact (Saulny 2008), this is an especially sensitive issue because the NAFTA treaty contains guarantees for foreign investors once international trade in a particular sector has been established, leading some prominent observers to warn of water exports becoming legally "locked in" (Barlow 2014). In the case of southwestern Ontario, Nestlé has denied allegations that water from its wells there is being transported across the international border, but some local water advocates point to anecdotal evidence that water bottled in Aberfoyle has been sold in the United States and elsewhere.

A third theme regards the potential harms of water bottling to local communities, including economic scarcity, due partly to the commodification it involves. Local elected officials in particular emphasized potential conflicts between rising water demand from population growth on the one hand, and continued or increased water extraction for bottling on the other. The uncommon water infrastructure legacy in this particular region-100 percent dependence on groundwater, rather than surface water from rivers or the Great Lakes - renders the finitude of local water far more apparent here than in other nearby regions, or indeed most North American communities. It also gives somewhat greater credibility to the "zero sum" arguments of some bottling critics - i.e., that residential and industrial uses are in direct competition for finite 
groundwater supplies. While the actual volume extracted for water bottling may be comparatively small relative to overall water use, the fact that key well sites - including the Middlebrook Well in Elora—-have been enclosed by Nestlé may indeed foreclose some options for local government to expand residential water supply to serve a growing regional population, thus potentially raising costs (to establish new source wells) and reducing water affordability.

As for our second research question, regarding the extent to which these discourses invoke distinct geographic scales, temporal framings, causes, and forms of water scarcity, the interview data reveal some interesting patterns. Zwarteveen and Boelens argue that analyses of movements for water justice "need to include an explicit understanding of how scales are used, constructed and entwined in hydrosocial dynamics and networks, among others, through political struggle" (2014, p. 152). In this vein, we find that many of the respondents engage- - whether consciously or not - in various forms of conflation regarding water scarcity. These include spatial conflation, in which respondents rhetorically equate water removal from specific watersheds or aquifers with drought that typically occurs on much larger geographic scales. They also illustrate a temporal conflation by linking recurring short-term drought to longer-term drawdown of water tables. Of course, these temporal scales are not mutually exclusive: droughts, for example, may be exacerbated or made more frequent by climate change. Finally, some respondents evince an attributional conflation that fuses volumetric or absolute scarcity with economic forms of scarcity, in which water could become inaccessible or unaffordable to households or local water utilities because of overextraction by industry.

As discussed at the outset, our objective here is not to critique respondents who use these rhetorical approaches, but rather to characterize the type of discursive work that such figurative conflation achieves. The attributional conflation in the Ontario case, for example, echoes the 
criticism by some observers of an overly simplistic link between growing population and scarcity that appears in some mainstream water management literature. For the respondents who vocalize this perspective, industrial extraction of water contributes to both economic and volumetric scarcity, given that those industrial users are given priority over residential use during periods of drought. More broadly, linking economic and volumetric scarcity in this way reprises the critiques by political economy/ecology scholars of facile formulations of scarcity that elide questions of power, politics, inequality, and justice.

Our final research question regards the implications of the analysis for water advocates and local communities in other similar settings and/or conflicts. An initial observation is that by dramatizing scarcity and highlighting water inequity, drought can serve to mobilize public concern. The timing of the more severe droughts of 2012 and 2016, just when Nestlé was seeking extensions of its bottling permits, was fortuitous for WWW and allied groups, allowing them to link local conditions to droughts occurring elsewhere as well as to broader concerns with climate change, eventually winning concessions in their battle with Nestlé. Thus, spatial and temporal conflation can be useful tools for water advocates, who seek to educate and mobilize the public by making connections between apparently disparate or unrelated phenomena. However, in crafting their strategic and tactical approaches, water advocates would also do well to consider the possible risks to credibility that such conflation might pose, particularly if the scale of the harms discussed is not clearly commensurate with the scale (or time frame) of drought and/or water extraction taking place.

Second, the removal of water from local aquifers and watersheds for consumption in other regions or nations - and the loss of control that this entails — was a potent theme in this study, suggesting that the choice of how to frame "local" water is an important strategic consideration. 
In addition to highlighting the local impacts of extraction, advocates in southwestern Ontario also effectively tapped into broader concerns about the loss of national sovereignty over freshwater. Third, concerns about the future (un)availability or shortage of water (either volumetric or economic) for local communities can be compelling, particularly when finiteness is as obvious as it is in groundwater-dependent regions such as this one. Finally, future economic scarcity is a potentially salient theme around which water advocates might mobilize in other settings. While the bottled water industry insists that the quantities it extracts are minor in relation to overall groundwater use, the enclosure of specific springs or wells by the industry potentially has major implications for the ability of local governments to protect groundwater sources and ensure reliable future water supplies for growing numbers of users. This, of course, mirrors the much broader global conflict between water as a commodity and water as a public good or a human right.

\section{Conclusion}

Since late 2016, developments in this conflict over water bottling in Ontario have taken a fairly dramatic turn. After announcing the two-year moratorium on new water bottling permits and substantially increasing extraction fees, Ontario Premier Kathleen Wynne went further, questioning the need for the commodity of bottled water itself. "I really think we need to look at the culture around bottled water," she told the Toronto Star. "Why are we all drinking water out of bottles when most of us don't need to?... I think we need to have a bigger look at the whole industry, and our role in regulating it" (Leslie 2016). Wynne also declared that "immediate improvements are needed when it comes to water bottling practices, particularly in the face of

climate change [and] the increasing demands on water resources by a growing population," and directed her Environment Minister to “improve Ontarians' access to refillable water stations in 
public and private spaces, [and] increase awareness of the rigorous standards municipal water systems must meet to provide the tap water most Ontarians drink" (Wynne 2016). This stancewhich directly embraced many of the critiques and demands of anti-bottled water advocateswas virtually unprecedented. Coupled with Toronto's 2008 ban on public purchases of bottled water, these moves have placed Ontario in the forefront internationally of regulating the industry and revalorizing public tap water.

The response from the bottled water industry to the changes was at least equally provocative. Elizabeth Griswold, Executive Director of the Canadian Bottled Water Association, wrote in an April 2017 op-ed piece:

Late in 2016, the Ontario government began a series of new initiatives which can only be described as a regulatory assault on the bottled water industry... [W] can only conclude that this has been driven by politics, in response to small but media savvy groups who oppose the industry... the Wynne Liberals have abandoned the government's traditional role as arbiters and adjudicators and have entered the fray on the side of those who oppose the bottled water industry. (Griswold 2017)

This remarkable statement suggests that the bottled water industry has been effectively shut out of provincial policymaking around water extraction, and that the water and environmental advocates in Wellington County have been effective in forcing greater regulation of this industry across Canada's most populous province. Moreover, as the quotes from Wynne illustrate, key politicians have actually adopted the water scarcity discourses and frames developed by these activists. On the other hand, Wellington Water Watchers and the Council of Canadians argue the recent policy changes are insufficient to protect groundwater, and are demanding a complete phase-out of the bottled water industry in Ontario within 10 years (Nagy and Barlow 2017).

Through an analysis of conflict over groundwater in southwestern Ontario, we have illustrated that participants in local contention over Nestlé's bottled water extraction discuss and publicize their efforts by mobilizing framings of scarcity that often conflate local, regional, 
national and global scales of drought and shortage; biophysical and economic limitations to water supply and access; and present and future time frames regarding conflicts between competing water uses. We suggest that these forms of figurative conflation illuminate the multilayered nature of the discursive terrain of local water contestation, as well as potentially fruitful strategies for advocates seeking to protect water supplies in similar settings involving the bottled water industry or groundwater mining by other large industrial water users.

This article contributes to scholarship on water scarcity in several ways: by analyzing the discursive element of a specific instance of local contention over water extraction; by examining a case study of conflict over water scarcity in a Northern setting where access to potable tap water is virtually universal; and by focusing on the industrial extraction of groundwater for the rapidly growing but inadequately studied commodity of bottled water.

This setting is in some ways far removed from the urgency of local struggles over water access experienced by people in more economically and politically marginalized communities in both South and North. Nevertheless, the commonalities between these contexts are also important and instructive. The conflicts in both Plachimada and Ontario, for example, involve active contestation over whose interests - those of powerful industries or local residents — will be privileged in allocating and regulating groundwater use, both temporally (present extraction for bottling versus future residents' needs) and spatially (removal from the aquifer/watershed versus reserving water for local uses). Both are characterized by at least partially successful efforts by local social movements to contest industrial enclosures of water by "denaturalizing" water scarcity and emphasizing its socially-produced character. We believe that the focus of these movements should indicate for scholars the importance of maintaining an emphasis on "how resource shortages and ecological degradation are primarily a result of the uneven social 
measures that manufacture scarcity all over the world for the economic and political gain of powerful interests" (Mehta 2007, p. 662). Further comparative research within and across such settings would contribute greatly to analyzing the complex terrain of increasing local contestation worldwide over "scarce" water. 


\section{REFERENCES}

Ahlers, R 2010. Fixing and nixing: the politics of water privatization. Review of Radical Political Economics 42 (2), 213-230.

Aiyer, A. 2007. The allure of the transnational: notes on some aspects of the political economy of water. Cultural Anthropology 22 (4), 640-658.

American Water Works Association. 2012. Buried no longer: confronting America's water infrastructure challenge. Denver: American Water Works Association. Available from: http://www.awwa.org/Portals/0/files/legreg/documents/BuriedNoLonger.pdf [Accessed 18 August 2017]

Bakker, K. 2000. Privatizing water, producing scarcity: the Yorkshire drought of 1995. Economic Geography 76 (1), 4-27.

Bakker, K. 2010. Privatizing water: governance failure and the world's urban water crisis. Ithaca, NY: Cornell University Press.

Barlow, M. 2014. Blue future: protecting water for people and the planet forever. New York: The New Press.

Benzie, R., 2017. Fees for bottlers of water jump from $\$ 3.71$ to $\$ 503.71$. The Toronto Star, 8 June. Available from: https://www.thestar.com/news/queenspark/2017/06/08/fees-forbottlers-of-water-jump-from-371-to-50371.html. [Accessed 6 August 2017].

Beverage Marketing Corporation. 2017. Bottled water becomes number-one beverage in the U.S., data from Beverage Marketing Corporation show. Troy, MI: Beverage Marketing Corporation.

Brei, V., and Tadajewski, M. 2015. Crafting the market for bottled water: a social praxeology approach. European Journal of Marketing 49 (3/4), 327-249.

Brown, T., 2015. Nestlé Waters: bottled water is not contributing to California's drought (OpEd). San Bernardino Sun, 28 April. Available from: http://www.sbsun.com/2015/04/28/nestl-waters-bottled-water-is-not-contributing-tocalifornias-drought/. [Accessed 28 April 2015].

Case, R. 2016a. Social work and the moral economy of water: community-based water activism and its implications for eco-social work. Critical Social Work, 17 (2). Available from: http://www1.uwindsor.ca/criticalsocialwork/MoralEconomyWater [Accessed September, $16,2017]$.

Case, R. 2016b. Eco-social work and community resilience: insights from water activism in Canada. Journal of Social Work, 17 (4), 391-412.

CBC News, 2015. Nestlé Waters Canada plan to tap aquifer worries Elora, Ont., residents. $C B C$ News Toronto, 29 October. Available from: http://www.cbc.ca/news/canada/toronto/nestlé-waters-canada-plan-to-tap-aquiferworries-elora-ont-residents-1.3295331. [Accessed 5 September 2017].

CTV News, 2016. Nestle seeking 10-year renewal of Aberfoyle water-taking permit. CTV News Kitchener, 14 April 14. Available from: http://kitchener.ctvnews.ca/guelph/nestleseeking-10-year-renewal-of-aberfoyle-water-taking-permit-1.2859636. [Accessed 5 September 2017].

Diekmann, L. O., Gray, L. C., and Baker, G. A. 2017. Drought, water access, and urban agriculture: a case study from Silicon Valley. Local Environment, 22 (11), 1394-1410.

Drew, G. 2008. From the groundwater up: asserting water rights in India. Development 51 (1), $37-41$. 
Drewnowski, A., Rehm, C. D., and Constant, F. 2013. Water and beverage consumption among adults in the United States: cross-sectional study using data from NHANES 2005-2010. BMC Public Health 13 (1), 1-19.

Emerson, R. M., Fretz, R. I., and Shaw, L. L. 2011. Writing ethnographic fieldnotes. 2nd ed. University of Chicago Press.

Euromonitor International. 2017. Bottled water in Canada: country report. Chicago, IL: Euromonitor International. Available from: http://www.euromonitor.com/bottled-waterin-canada/report. [Accessed 24 August 2017].

Fumano, D. 2013. The 'wild west' of groundwater: billion-dollar Nestlé extracting B.C.'s drinking water for free. The Province, 14 August. Available from: http://www.timescolonist.com/news/local/wild-west-of-groundwater-billion-dollarnestlé-extracting-b-c-s-drinking-water-for-free-1.587568. [Accessed 14 June 2017].

Gentile, A. 2008. Mayors push benefits of cities' tap water. American City \& County 123 (9), $18-20$.

Gleick, P. H. 2010. Bottled and sold: the story behind our obsession with bottled water. Washington, DC: Island Press.

Gleick, P.H., and Cooley, H.S. 2009. Energy implications of bottled water. Environmental Research Letters 4 (1), 1-6.

GRCA. 2016. Appendix A: Assessment report of the Grand River watershed. The drinking water source protection plan for the Grand River source protection area. Cambridge, ON: Grand River Conservation Authority.

Greene, J. C. 2014. The bottled water industry in Mexico. Thesis (Master of Global Policy Studies). University of Texas at Austin.

Griswold, E. 2017. Ontario government has taken sides against the bottled water industry. The Toronto Star, 10 April 10. Available from: https://www.thestar.com/opinion/commentary/2017/04/10/ontario-government-has-takensides-against-the-bottled-water-industry.html. [Accessed 24 April 2017].

Gumbel, A. 2015. California drought spurs protest over 'unconscionable' bott]led water business. The Guardian, 19 April. Available from: https://www.theguardian.com/usnews/2015/apr/19/california-drought-protest-bottled-water. [Accessed 27 April 2017].

Harvey, D. 1974. Population, resources and the ideology of science. Economic Geography 50, 256-277.

Hawkins, G. 2017. The impacts of bottled water: an analysis of bottled water markets and their interactions with tap water provision. WIREs Water 4 (3). doi: 10.1002/wat2.1203.

Hawkins, G, Potter, E., and Race, K. 2015. Plastic water: the social and material life of bottled water. Cambridge, MA: MIT Press.

Hawkins, R, and Emel, J. 2014. Paradoxes of ethically branded bottled water: constituting the solution to the world water crisis. Cultural Geographies 21 (4), 727-743.

Hecht, P. 2015. Bottled water companies under fire amid California's drought. Sacramento Bee, 14 May. Available from: http://www.sacbee.com/news/state/california/water-anddrought/article21049293.html. [Accessed 3 August 2017].

Holt, D. B. 2012. Constructing sustainable consumption: from ethical values to the cultural transformation of unsustainable markets. The Annals of the American Academy of Political and Social Science 644 (1), 236-255.

Ioris, A. R. 2012. the geography of multiple scarcities: urban development and water problems in Lima, Peru. Geoforum 43, 612-622. 
Ioris, A. R. 2013. The adaptive nature of the neoliberal state and the state-led neoliberalisation of nature: unpacking the political economy of water in Lima, Peru. New Political Economy $18(6), 912-938$.

Jaeger, K. W., et al. 2013. Toward a formal definition of water scarcity in natural-human systems. Water Resources Research 49 (7), 4506-4517.

Jaffee, D., and Newman, S. 2013a. A bottle half empty: bottled water, commodification, and contestation. Organization \& Environment 26 (3), 318-335.

Jaffee, D., and Newman, S. 2013b. A more perfect commodity: bottled water, global accumulation, and local contestation. Rural Sociology 78 (1), 1-28.

Jairath, J. 2010. Advocacy of water scarcity: leakages in the argument. In L. Mehta. The limits to scarcity: contesting the politics of allocation. Washington, D.C.: Earthscan, 215-232.

James, I., 2015. Bottling water without scrutiny. The Desert Sun, 8 March. Available from: http://www.desertsun.com/story/news/2015/03/05/bottling-water-californiadrought/24389417/. [Accessed 29 April 2017].

Joy, K.J., Kulkarni, S., Roth, D, and Zwarteveen, M. 2014. re-politicising water governance: exploring water re-allocations in terms of justice. Local Environment 19 (9), 954-973.

Kaika, M. 2003. Constructing scarcity and sensationalizing water politics: 170 days that shook Athens. Antipode 35 (5), 919-954.

Kassam, A., 2016. Canadian town steams over Nestlé bid to control local spring water well. The Guardian, 24 September 24. Available from:

https://www.theguardian.com/world/2016/sep/24/canada-nestle-water-well-bid-centrewellington [Accessed 24 August 2017].

Lagos, M., 2014. S. F. supervisors back ban on sale of plastic water bottles. San Francisco Chronicle, 5 March 5. Available from: http://www.sfgate.com/bayarea/article/S-Fsupervisors-back-ban-on-sale-of-plastic-5289089.php. [Accessed 5 May 2014].

Laville, S. and Taylor, M., 2017. A million bottles a minute: world's plastic binge 'as dangerous as climate change'. The Guardian, 28 June. Available from:

https://www.theguardian.com/environment/2017/jun/28/a-million-a-minute-worldsplastic-bottle-binge-as-dangerous-as-climate-change. [Accessed 7 September 2017].

Leslie, K., 2016. Premier Wynne wants 'bigger look' at future of bottled-water industry. The Toronto Star, 21 December 21. Available from: https://www.thestar.com/business/2016/12/21/premier-wynne-wants-bigger-look-atfuture-of-bottled-water-industry.html. [Accessed 7 September 2017].

Loftus, A. 2009. Rethinking political ecologies of water. Third World Quarterly 30 (5), 953968.

Marx, K. 1867. Capital: a critique of political economy. Chicago: Charles H. Kerr \& Co.

Mehta, L. 2007. Whose scarcity? Whose property? The case of water in western India. Land Use Policy 24 (4), 654-663.

Mehta, L., ed., 2010. The limits to scarcity: contesting the politics of allocation. London: Earthscan.

Mehta, L. 2014. Water and human development. World Development 59, 59-69.

Miller, G. 2007. Reconciling our priorities: Annual report for 2006/07. Toronto: Environmental Commissioner of Ontario.

Nagy, M., and Barlow, M., 2017. Time for Ontario to protect its water supplies. The Record, 11 May 11. Available from: https://www.therecord.com/opinion-story/7309925-time-forontario-to-protect-its-water-supplies/. [Accessed 21 July 2017]. 
Neate, R., 2015. Nestlé boss says he wants to bottle more water in California despite drought. The Guardian, 14 May 14. Available from: https://www.theguardian.com/usnews/2015/may/14/nestle-boss-wants-bottle-more-water-california-drought. [Accessed 21 April 2017].

Nestlé Waters Canada, 2016. Nestlé in Canada. Available from: https://www.corporate.nestle.ca/en/ask-nestle/documents/nestle $\% 20$ $\% 20$ fact\%20sheet\%20(sept.\%202016).pdf.[Accessed 2 September 2017].

Nestlé Waters North America. 2013. About Nestlé Waters North America. Availabe from: https://www.nestle-watersna.com/en/about-nestle-waters. [Accessed 18 August 2017].

NRDC. 1999. Bottled Water: Pure Drink or Pure Hype? Washington, DC: Natural Resources Defense Council.

Otero, I., Kallis, G., Aguilar, R. and Ruiz, V. 2011. Water scarcity, social power and the production of an elite suburb: the political ecology of water in Matadepera, Catalonia. Ecological Economics 70 (7), 1297-1308.

Paris, M., 2013. Groups want cap on Nestlé's water permit during droughts. $C B C$ News, 3 June. Available from: http://www.cbc.ca/news/politics/groups-want-cap-on-nestlé-s-waterpermit-during-droughts-1.1344958. [Accessed 12 September 2017].

Perreault, T. 2013. Dispossession by accumulation? Mining, water and the nature of enclosure on the Bolivian Altiplano. Antipode 45 (5), 1050-1069.

Province of Ontario. 2017. Growth plan for the Greater Golden Horseshoe, 2017. Toronto: Ontario Ministry of Municipal Affairs.

Raman, K. R. 2010. Transverse solidarity: water, power, and resistance. Review of Radical Political Economics 42 (2), 251-268.

Rijsberman, F. R. 2006. Water scarcity: fact or fiction? Agricultural Water Management 80 (1), 5-22.

Roberts, A. 2008. Privatizing social reproduction: the primitive accumulation of water in an era of neoliberalism. Antipode 40 (4), 535-560.

Rodwan, J.G. 2017. Bottled water 2016: No. 1 and growing: U.S. and international developments and statistics. Bottled Water Reporter 57 (4 (July/Aug)), 12-21.

Rosemann, N. 2005. Drinking water crisis in Pakistan and the issue of bottled water: the case of Nestlé's 'Pure Life.' Berne, Switzerland: ActionAid.

Saulny, S., 2008. Ban near on diverting water from Great Lakes. The New York Times, 22 September. Available from: http://www.nytimes.com/2008/09/23/us/23lakes.html. [Accessed 11 September 2017].

Save Our Water. n.d. About us: who is Save Our Water. Available from: http://www.saveourwater.ca/about. [Accessed 3 September 2017].

Sen, A. K. 1999. Development as freedom. Oxford University Press.

Sitisarn, S. 2012. Political ecology of the soft drink and bottled water business in India; a case study of Plachimada. Thesis (Master's). Lund University.

Snitow, A., Kaufman, D. and Fox. M. 2007. Thirst: fighting the corporate theft of our water. San Francisco: Wiley \& Sons.

Spiliotis, M., and Garrote, L. 2015. A fuzzy multicriteria categorization of water scarcity in complex water resources systems. Water Resource Management 29, 521-539.

Spronk, S. and Webber, J. R. 2007. Struggles against accumulation by dispossession in Bolivia: the political economy of natural resource contention. Latin American Perspectives 34 (2), 31-47. 
Statistics Canada. 2016b. Census Profile, 2016 Census: Wellington County, Ontario. Ottawa: Statistics Canada.

Swyngedouw, E. 2009. The political economy and political ecology of the hydro-social cycle. Journal of Contemporary Water Research \& Education 142 (1), 56-60.

Szasz, A. 2007. Shopping our way to safety: how we changed from protecting the environment to protecting ourselves. Minneapolis: University of Minnesota Press.

Torres, I.V. 2012. Water grabbing in the Cauca Basin: the capitalist exploitation of water and dispossession of afro-descendant communities. Water Alternatives 5 (2), 431-449.

Transparency Market Research. 2015. Bottled water market: global industry analysis, size, share, growth, trends and forecast, 2014-2020. Transparency Market Research.

Wagner, T. 2016. Flint is swimming in water bottles. Marketplace.org, 26 January. Available from: https://www.marketplace.org/2016/01/26/sustainability/flint-swimming-waterbottles. [Accessed 22 April 2016].

Wellington Water Watchers. n.d. About us--Wellington Water Watchers. Available from: http://wellingtonwaterwatchers.ca/about-us/. [Accessed 13 September 2017].

Wilk, R. 2006. Bottled water: the pure commodity in the age of branding. Journal of Consumer Culture 6 (3), 303-325

Wynne, K. 2016. September 2016 mandate letter: Environment and Climate Change: Premier's instructions to the Minister on priorities. Government of Ontario. Available from: https://www.ontario.ca/page/september-2016-mandate-letter-environment-and-climatechange. [Accessed 12 September 2017]

Zwarteveen, M. Z., \& Boelens, R. (2014). Defining, researching and struggling for water justice: some conceptual building blocks for research and action. Water International 39 (2), 143158. 